Irena Pyka*

\title{
KREACJA PIENIĄDZA KREDYTOWEGO W WARUNKACH POLITYKI LUZOWANIA ILOŚCIOWEGO BANKÓW CENTRALNYCH
}

\section{Wprowadzenie}

Polityka luzowania ilościowego realizowana przez największe banki centralne w różnych programach skupu papierów wartościowych spowodowała wyhamowanie procesów recesyjnych i pewne pozytywne efekty w sferze realnej. Gospodarka światowa z fazy kryzysu nie weszła jednak na ścieżkę dynamicznego wzrostu gospodarczego. W Stanach Zjednoczonych i strefie euro obserwuje się natomiast dość znaczne zróżnicowanie aktualnych tendencji gospodarczych. Wyższej dynamice wzrostu gospodarczego, spadkowi bezrobocia i lepszemu zbilansowaniu budżetów gospodarstw domowych w USA towarzyszy odmienna sytuacja w strefie euro: bardzo niski wzrost gospodarczy, niekorzystna kondycja rynku pracy i stale wysoki poziom zadłużenia publicznego. Sytuację tę tłumaczy się często istniejącą dywergencją cykli polityki pieniężnej w USA i strefie euro. W opracowaniu natomiast wskazuje się, że zasadniczą przyczyną obserwowanych trendów w gospodarce analizowanych stref są różnice w polityce luzowania ilościowego Fed i EBC. Mechanizm luzowania ilościowego nie jest bowiem równoznaczny z emisją pustego pieniądza. W zależności od konstrukcji programu luzowania ilościowego może ono prowadzić do wzrostu ilości pieniądza w obiegu i nasilenia się procesów inflacyjnych. Może jednak również, poprzez zmianę struktury aktywów bilansowych banków centralnych, wpływać na wzrost pieniądza rezerwowego banku centralnego i rentowność instrumentów finansowych, hamując efekt majątkowy gromadzonych oszczędności, jednocześnie stymulując procesy deflacyjne.

* Uniwersytet Ekonomiczny w Katowicach, Wydział Finansów i Ubezpieczeń. 


\section{Analiza porównawcza programów luzowania ilościowego Fed i EBC}

W latach 2008-2014, a zatem od momentu eskalacji globalnego kryzysu finansowego, banki centralne przygotowały wiele programów wykupu aktywów finansowych. Tabela 1 prezentuje te, które realizowane były przez Fed.

Większość z nich oparta została na finansowaniu pod zastaw papierów wartościowych różnych uczestników rynku pieniężnego w USA. Za klasyczną formę luzowania ilościowego uznaje się jednak tylko te programy wykupu papierów wartościowych, których efektem jest dodruk pieniądza gotówkowego. Taką formę wykupu aktywów finansowych określa się direct quantitative easing ${ }^{1}$.

Fed program wykupu papierów wartościowych realizował w trzech kolejnych rundach określonych QE1, QE2, QE3. Pierwsza faza wykupu ilościowego nazwana programem LSAP (Large-Scale Asset Purchasses) rozpoczęła się pod koniec $2008 \mathrm{r}$. Od grudnia 2008 do marca 2010 r. Fed dokonał skupu papierów wartościowych na ponad 1,7 bln UDS². W listopadzie 2010 r. wskutek tego, iż spodziewane cele związane z ożywieniem gospodarczym i rozluźnieniem warunków kredytowania nie zostały zrealizowane zgodnie z oczekiwaniami, rozpoczęła się druga runda QE2, a dwa lata później QE3 silnie związana z programem wykupu papierów wartościowych określanych potocznie operacją Twist (Operation Twist) ${ }^{3}$. Pod koniec czerwca 2013 r. Fed ogłosił stopniowe ograniczanie polityki luzowania ilościowego, a z początkiem roku 2015 ich całkowite zakończenie.

EBC w odróżnieniu od Fed na początku globalnego kryzysu finansowego, pomimo angażowania się $\mathrm{w}$ transakcje papierami wartościowymi, nie tworzył specjalnych programów wykupu aktywów finansowych. Przede wszystkim rozszerzał zestaw aktywów finansowych akceptowanych jako zabezpieczenie transakcji w operacjach otwartego rynku i zwiększył termin zapadalności długoterminowych operacji refinansowych LTRO (Longer Term Refinancing Operations).

\footnotetext{
1 L.B. Smaghi, Conventional and uncoventional monetary policy, Keynote lecture at the International Center for Monetary and Banking Studies (ICMB), Geneva, 28 April 2009, s. 3 i nast.

2 J. Gagnon, M. Raskin, J. Remarche, B. Sack, Large-Skale Asset Purchasses by the Federal Reserwe: Did the Work?, "Federal Reserve Bank of New York Staff Reports" 2010, No. 441, March, s. 8.

3 P. Inman; What is Operation Twist?, "The Guardian" http://www.theguardian.com/business/2011/ sep/21/operation-twist-federal-resrve-gamble-us-economic-stimulus.
} 
Tabela 1. Główne programy wykupu aktywów finansowych (papierów wartościowych) przez Fed w latach $2007-2014$

\begin{tabular}{|c|c|c|c|c|c|c|}
\hline Lp. & $\begin{array}{l}\text { Czas trwania } \\
\text { programu }\end{array}$ & $\begin{array}{l}\text { Nazwa } \\
\text { programu }\end{array}$ & $\begin{array}{l}\text { Wartość } \\
\text { programu }\end{array}$ & $\begin{array}{c}\text { Forma } \\
\text { zabezpieczenia } \\
\text { pożyczki }\end{array}$ & $\begin{array}{l}\text { Uczestnicy } \\
\text { programu }\end{array}$ & Cel programu \\
\hline 1. & $\begin{array}{l}12.12 .2007- \\
-11.03 .2010\end{array}$ & $\begin{array}{l}\text { TAF (Term } \\
\text { Auction Facility) }\end{array}$ & 3,82 bln USD & $\begin{array}{l}\text { Aktywa finansowe } \\
\text { wysokiej jakości } \\
\text { o standardach } \\
\text { nadzorczych. } \\
\text { Uruchomione } \\
\text { kredyty i szeroki } \\
\text { zakres papierów } \\
\text { wartościowych } \\
\text { - w tym MBS-y, } \\
\text { CD0, CLO } \\
\text { o ratingu AAA }\end{array}$ & $\begin{array}{l}\text { Instytucje } \\
\text { depozytowe } \\
\text { (banki) } \\
\text { o wysokiej } \\
\text { kondycji } \\
\text { finansowej } \\
\text { dopuszczone do } \\
\text { finansowania } \\
\text { w ramach okna } \\
\text { dyskontowego }\end{array}$ & $\begin{array}{l}\text { Złagodzenie } \\
\text { napięć na rynku } \\
\text { pieniężnym } \\
\text { poprzez } \\
\text { dystrybucję } \\
\text { płynności } \\
\text { na rynku } \\
\text { międzybankowym }\end{array}$ \\
\hline 2. & $\begin{array}{l}11.03 .2008- \\
-1.02 .2010\end{array}$ & $\begin{array}{l}\text { TSLF (Term } \\
\text { Securities } \\
\text { Lending } \\
\text { Facility) }\end{array}$ & $\begin{array}{l}235,5 \mathrm{mld} \text { na } \\
1.10 .2008\end{array}$ & $\begin{array}{l}\text { Papiery dłużne } \\
\text { skarbowe agencji } \\
\text { rządowych, } \\
\text { papiery } \\
\text { komunalne, } \\
\text { MBS-y i ABS-y }\end{array}$ & $\begin{array}{l}\text { Primacy dealers } \\
\text { - dilerzy rynku } \\
\text { pieniężnego }\end{array}$ & $\begin{array}{l}\text { Zwiększenie } \\
\text { płynności } \\
\text { rynku papierów } \\
\text { wartościowych } \\
\text { poprzez } \\
\text { funkcjonowanie } \\
\text { rynku } \\
\text { finansowego } \\
\text { w USA }\end{array}$ \\
\hline 3. & $\begin{array}{l}16.03 .2008- \\
-1.02 .2010\end{array}$ & $\begin{array}{l}\text { PDCF (Primary } \\
\text { Dealer Credit } \\
\text { Facility) }\end{array}$ & $\begin{array}{l}\text { Różna } \\
\text { okresowa, } \\
\text { po wdrożeniu } \\
37 \text { mld USD } \\
\text { spadła } \\
\text { pod koniec } \\
\text { zakończenia } \\
\text { finansowania }\end{array}$ & $\begin{array}{l}\text { Papiery } \\
\text { wartościowe } \\
\text { akceptowane } \\
\text { tradycyjnie } \\
\text { w operacjach repo }\end{array}$ & $\begin{array}{l}\text { Primacy dealers } \\
\text { - dilerzy rynku } \\
\text { pieniężnego }\end{array}$ & $\begin{array}{l}\text { Zwiększenie } \\
\text { zdolności dilerów } \\
\text { rynku pieniężnego } \\
\text { do działania } \\
\text { w zakresie } \\
\text { finansów } \\
\text { uczestników rynku } \\
\text { sekurytyzowanych } \\
\text { papierów } \\
\text { wartościowych, } \\
\text { dla lepszego } \\
\text { funkcjonowania } \\
\text { rynku } \\
\text { finansowego }\end{array}$ \\
\hline 4. & $\begin{array}{l}19.09 .2008- \\
-1.02 .2010\end{array}$ & $\begin{array}{l}\text { AMLF (Asset } \\
\text { - Backet } \\
\text { Commercial } \\
\text { Paper Money } \\
\text { Market Mutual } \\
\text { Fund Liquidity } \\
\text { Facility) }\end{array}$ & $\begin{array}{l}\text { Okresowo } \\
\text { zróżnicowana, } \\
\text { na początku } \\
\text { programu } \\
\text { najwyższa } \\
\text { - październik } \\
2008 \\
152,1 \text { mld USD }\end{array}$ & $\begin{array}{l}\text { Papiery } \\
\text { komercyjne } \\
\text { zabezpieczone } \\
\text { aktywami (ABCP) }\end{array}$ & $\begin{array}{l}\text { Instytucje } \\
\text { depozytowe } \\
\text { i holdingi } \\
\text { bankowe }\end{array}$ & $\begin{array}{l}\text { Wzrost płynności } \\
\text { na rynkach } \\
\text { papierów } \\
\text { komercyjnych, } \\
\text { zabezpieczonych } \\
\text { aktywach } \\
\text { i zapewnienie } \\
\text { środków } \\
\text { finansowych } \\
\text { funduszami rynku } \\
\text { pieniężnego }\end{array}$ \\
\hline 5. & $\begin{array}{l}7.10 .2008- \\
-1.02 .2010\end{array}$ & $\begin{array}{l}\text { CPFF } \\
\text { (Commercial } \\
\text { Paper Funding } \\
\text { Facility) }\end{array}$ & - & $\begin{array}{l}\text { Trzymiesięczne } \\
\text { papiery } \\
\text { komercyjne }\end{array}$ & $\begin{array}{l}\text { Emitenci } \\
\text { papierów } \\
\text { komercyjnych }\end{array}$ & $\begin{array}{l}\text { Zapewnienie } \\
\text { płynności } \\
\text { rynku papierów } \\
\text { komercyjnych }\end{array}$ \\
\hline
\end{tabular}




\begin{tabular}{|c|c|c|c|c|c|c|}
\hline Lp. & $\begin{array}{c}\text { Czas trwania } \\
\text { programu }\end{array}$ & $\begin{array}{c}\text { Nazwa } \\
\text { programu }\end{array}$ & $\begin{array}{l}\text { Wartość } \\
\text { programu }\end{array}$ & $\begin{array}{c}\text { Forma } \\
\text { zabezpieczenia } \\
\text { pożyczki }\end{array}$ & $\begin{array}{l}\text { Uczestnicy } \\
\text { programu }\end{array}$ & Cel programu \\
\hline 6. & \begin{tabular}{|l|}
$25.11 .2008-$ \\
-30.06 .2010 \\
aktywny do 2012
\end{tabular} & $\begin{array}{l}\text { TALF (Term } \\
\text { Asset-Backed } \\
\text { Securities Loan } \\
\text { Facility) }\end{array}$ & $\begin{array}{l}\text { Wielkość } \\
\text { wsparcia } \\
200 \text { mld USD } \\
\text { z możliwością } \\
\text { zwiększenia do } \\
1 \text { bln USD }\end{array}$ & ABS & $\begin{array}{l}\text { Przedsiębiorstwa } \\
\text { uprawnione } \\
\text { przez program }\end{array}$ & $\begin{array}{l}\text { Zwiększenie } \\
\text { dostepności } \\
\text { kredytów dla } \\
\text { gospodarstw } \\
\text { domowych }\end{array}$ \\
\hline 7. & $\begin{array}{l}25.11 .2008- \\
-6.2011\end{array}$ & $\begin{array}{l}\text { LSAP (Large } \\
\text { Scale Asset } \\
\text { Purchase) }\end{array}$ & 2700 mld USD & $\begin{array}{l}\text { MBS-y, papiery } \\
\text { wartościowe OSE, } \\
\text { długoterminowe } \\
\text { papiery rządowe }\end{array}$ & $\begin{array}{l}\text { Uczestnicy rynku } \\
\text { nieruchomości } \\
\text { i kredytów } \\
\text { hipotecznych }\end{array}$ & $\begin{array}{l}\text { Interwencje } \\
\text { Fed na rynku } \\
\text { kredytowym } \\
\text { celem wpływu } \\
\text { na cenę długu } \\
\text { długoterminowych, } \\
\text { rynkowych stóp } \\
\text { procentowych } \\
\end{array}$ \\
\hline 8. & $\begin{array}{l}21.09 .2011 \\
\text { - poczatkowo } \\
\text { czerwiec } \\
2012 \text {, a potem } \\
\text { wydłużony do } \\
2014 \text { i połowy } \\
2015\end{array}$ & $\begin{array}{l}\text { Twist - MEP } \\
\text { Maturity } \\
\text { Extension } \\
\text { Program }\end{array}$ & $8,8 \mathrm{mld}$ USD & \begin{tabular}{|l|} 
Obligacje \\
skarbowe \\
z portfela \\
inwestycji \\
bilansowych Fed
\end{tabular} & $\begin{array}{l}\text { Gospodarstwa } \\
\text { domowe o długu } \\
\text { hipotecznym }\end{array}$ & $\begin{array}{l}\text { Obniżanie stóp } \\
\text { procentowych } \\
\text { w celu obniżenia } \\
\text { kosztów kredytów } \\
\text { hipotecznych }\end{array}$ \\
\hline
\end{tabular}

Źródło: Opracowanie własne.

Tabela 2 prezentuje wykorzystane przez EBC programy wykupu aktywów finansowych. Pierwszym z nich był program zakupu listów zastawnych (Covered Bond Purchase Programme, CBPP) skierowany głównie na poprawę płynności rynku bankowego strefy euro. Jednak za oficjalny program papierów wartościowych EBC uznawany jest ogłoszony w maju $2010 \mathrm{r}$. Securities Markets Programme (SMP). Cechą charakterystyczną programu było to, że EBC zasoby płynności - wynikające ze skupu obligacji w ramach ogłoszonego programu - w całości, za pomocą specjalnych operacji, wchłaniał z powrotem. Na koniec $2010 \mathrm{r}$. łączna kwota interwencji Eurosystemu na rynkach obligacji wyniosła 73,5 mld EURO - dokładnie tyle samo, co zasoby płynności zaabsorbowane z rynku pieniężnego ${ }^{4}$. We wrześniu 2012 r. EBC ogłosił kolejny program papierów wartościowych Outright Monetary Transactions (OMT). Ważnym czynnikiem jego uruchomienia była przedłużająca się silna segmentacja rynku finansowego wywołana kryzysem związanym $z$ długiem państwowym.

Natomiast stale niska koniunktura gospodarcza w strefie euro, wysokie zadłużenie publiczne państw członkowskich, a także wiele innych problemów tej wspólnotowej gospodarki europejskiej spowodowały, że pod koniec roku 2011 EBC zdecydował się na uzupełnienie istniejących programów płynnościowych wznowionym CBPP oraz rocznymi i trzyletnimi LTRO. W przeciwieństwie też do Fed, do roku 2015 nie

\footnotetext{
4 Raport Roczny 2010, EBC, s. 19-21.
} 
zdecydował się na realizację strategii wyjścia z nadzwyczajnej polityki monetarnej i zapowiada jej kontynuację.

Tabela 2. Programy wykupu papierów wartościowych przez EBC w latach 2008-2014

\begin{tabular}{|c|c|c|c|c|c|c|}
\hline Lp. & Czas trwania & Nazwa & Wartość & $\begin{array}{c}\text { Forma } \\
\text { zabezpieczenia }\end{array}$ & Uczestnicy & Cel \\
\hline 1. & $\begin{array}{l}\text { lipiec 2009_- } \\
\text {-czerwiec } 2010\end{array}$ & $\begin{array}{l}\text { CBPP (Covered } \\
\text { Bord Purchase } \\
\text { Programme) }\end{array}$ & $60 \mathrm{mld}$ EUR & $\begin{array}{l}\text { Listy zastawne, } \\
\text { obligacje } \\
\text { zabezpieczone }\end{array}$ & Banki strefy euro & $\begin{array}{l}\text { Wsparcie } \\
\text { płynności rynku } \\
\text { międzybankowego } \\
\text { strefy euro i rynku } \\
\text { prywatnych } \\
\text { papierów } \\
\text { wartościowych, } \\
\text { krótkoterminowe } \\
\text { finansowanie } \\
\text { banków, } \\
\text { zwiększenie akcji } \\
\text { kredytowej }\end{array}$ \\
\hline 2. & $\begin{array}{l}\text { maj 2010- } \\
\text {-początek } 2012\end{array}$ & $\begin{array}{l}\text { SMP (Securities } \\
\text { Market } \\
\text { Programme) }\end{array}$ & $220 \mathrm{mld}$ EUR & $\begin{array}{l}\text { Publiczne } \\
\text { i prywatne } \\
\text { dłużne papiery } \\
\text { wartościowe }\end{array}$ & Banki & $\begin{array}{l}\text { Dostęp do źródeł } \\
\text { finansowych } \\
\text { banków, wzrost } \\
\text { akcji kredytowej }\end{array}$ \\
\hline 3. & $\begin{array}{l}\text { listopad 2011- } \\
\text {-październik } \\
2012\end{array}$ & $\begin{array}{l}\text { CBPP } 2 \text { (Covered } \\
\text { Bord Purchase) } \\
\text { Programme) }\end{array}$ & $40 \mathrm{mld}$ EUR & $\begin{array}{l}\text { Obligacje } \\
\text { zabezpieczone }\end{array}$ & $\begin{array}{l}\text { Banki } \\
\text { i przedsiębiorstwa } \\
\text { strefy euro }\end{array}$ & $\begin{array}{l}\text { Lepsze } \\
\text { finansowanie } \\
\text { banków } \\
\text { i przedsiębiorstw }\end{array}$ \\
\hline 4. & $\begin{array}{l}\text { 6.09.2012 - brak } \\
\text { przewidywania } \\
\text { czasowego }\end{array}$ & $\begin{array}{l}\text { OMT (Outright } \\
\text { Monetary } \\
\text { Transactions) }\end{array}$ & - & $\begin{array}{l}\text { Rządowe papiery } \\
\text { dłużne strefy euro }\end{array}$ & $\begin{array}{l}\text { Uczestnicy } \\
\text { rynków } \\
\text { prywatnych } \\
\text { strefy euro za } \\
\text { pośrednictwem } \\
\text { funduszu } \\
\text { ratunkowego, }\end{array}$ & $\begin{array}{l}\text { Zachowanie } \\
\text { jednolitej polityki } \\
\text { monetarnej, } \\
\text { ograniczenie } \\
\text { zakłóceń } \\
\text { na rynkach } \\
\text { obligacji } \\
\text { rządowych strefy } \\
\text { euro, obniżka } \\
\text { kosztów }\end{array}$ \\
\hline 5. & $\begin{array}{l}\text { grudzień 2011- } \\
\text {-luty } 2012\end{array}$ & LTRO & $\begin{array}{l}489 \mathrm{mld} \text { EUR } \\
529 \mathrm{mld} \text { EUR }\end{array}$ & $\begin{array}{l}\text { Aktywa } \\
\text { kwalifikowane } \\
\text { w 00R strefy euro }\end{array}$ & Banki & $\begin{array}{l}\text { Refinansowanie } \\
\text { banków }\end{array}$ \\
\hline
\end{tabular}

Źródło: Opracowanie własne.

\section{Podaż pieniądza kredytowego w USA i strefie euro w latach 2010-2014}

Globalny kryzys finansowy w opinii obserwatorów i analityków życia gospodarczego skończył się w roku 2010. W latach 2010-2014, analizowanych w opracowaniu, gospodarka światowa zaczyna wychodzić z recesji. Po kryzysie finansowym, 
który zawsze podważa wzajemne zaufanie instytucji finansowych i obniża kapitał bankowy, paradoksalnie, dynamiczny wzrost gospodarczy jest jednocześnie silnie uwarunkowany przyrostem kredytów dla podmiotów niefinansowych (przedsiębiorstw produkcyjnych). Rysunek 1 przedstawia roczne tempo wzrostu akcji kredytowej w USA. Można zauważyć, że chociaż w całym badanym okresie było ono nierównomierne, to jednak od roku 2010 następuje jego stały wzrost, wyraźnie silniejszy od połowy roku 2013.

\section{Rysunek 1. Roczne tempo wzrostu akcji kredytowej w Stanach Zjednoczonych w latach 2010-2014 (w \%)}

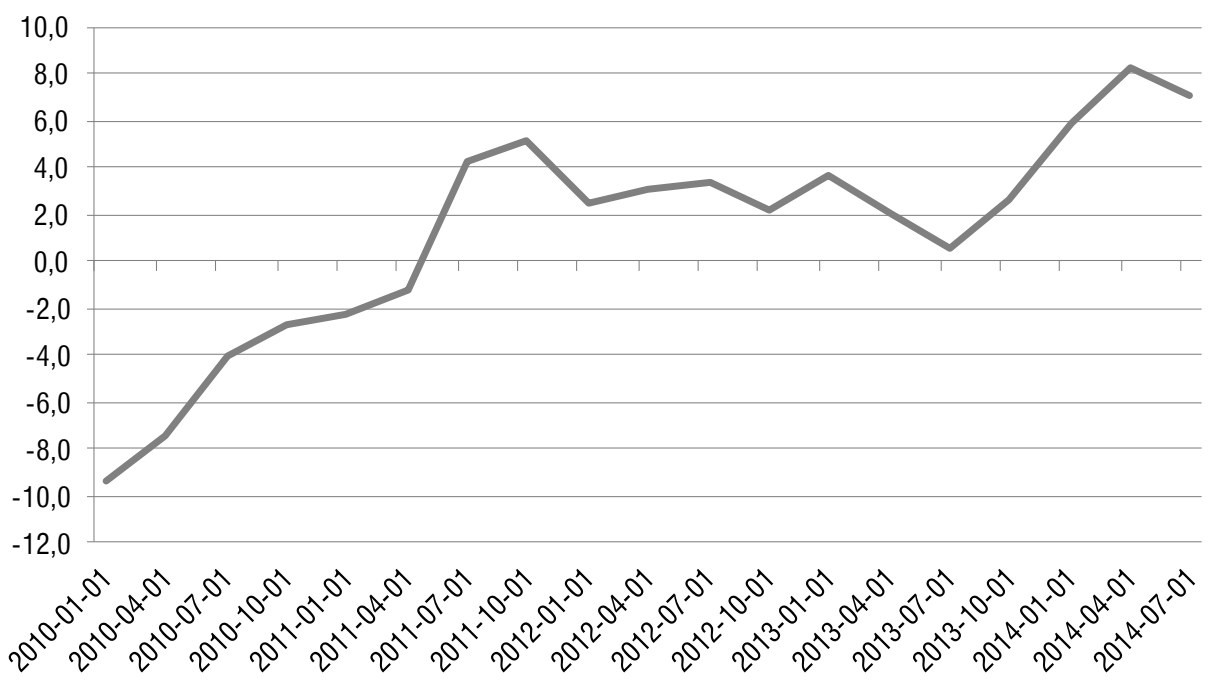

Źródło: https://research.stlouisfed.org/fred2/series/LLBACBQ158SBOG\#, dostęp 26.02.2015.

W tym samym okresie roczna stopa wzrostu kredytów i pożyczek bankowych dla sektora prywatnego w strefie euro - początkowo rosnąca, pod koniec badanego okresu, a zatem w latach 2012-2013 - spadła (rysunek 2).

Zauważyć także należy, że prowadzona w tym okresie polityka luzowania ilościowego Fed i EBC doprowadziła w obydwu bankach centralnych do szybszego wzrostu ich bazy monetarnej niż podaży pieniądza bankowego mierzonego agregatami monetarnymi (rysunek 3 i 4 ).

W latach 2010-2014 przyrost bazy monetarnej w USA był jednak silniejszy niż w strefie euro. Baza monetarna EBC podobnie więc jak baza monetarna FED, rosła. Wzrost bazy monetarnej w EBC był jednak mniej równomierny, a w roku 2013 wielkość bazy monetarnej w EBC mocno spadła (rysunek 3 i 4). 
Rysunek 2. M3 a kredyty i pożyczki dla sektora prywatnego w strefie euro (roczne zmiany w \%; skorygowane o efekty sezonowe i kalendarzowe)

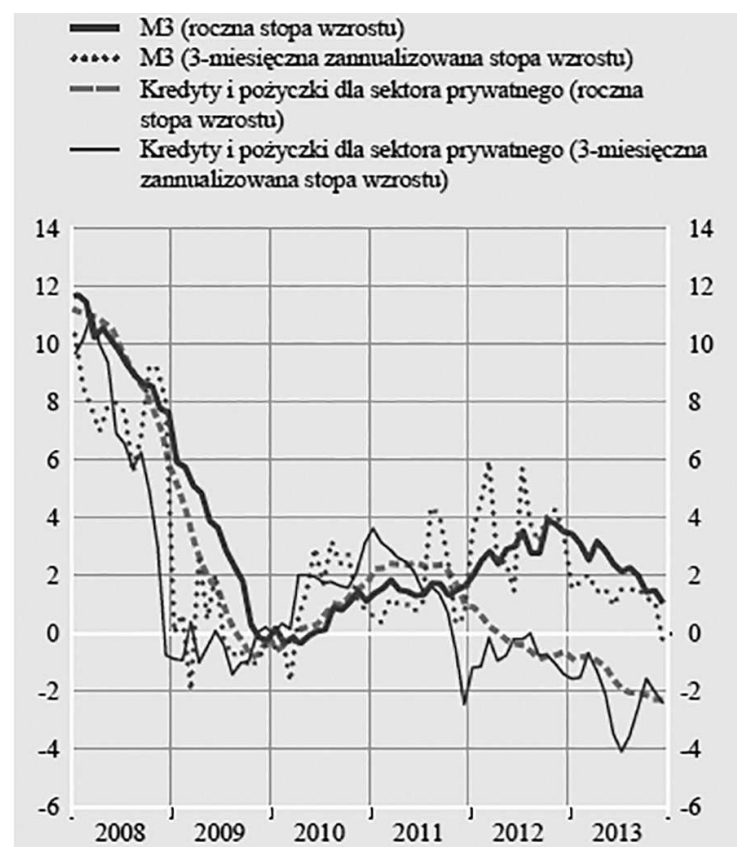

Źródło: EBC

Rysunek 3. Indeksy bazy monetarnej oraz agregatów M1 i M2 w Stanach Zjednoczonych w latach 2010-2014 (w \%, rok $2008=100)$

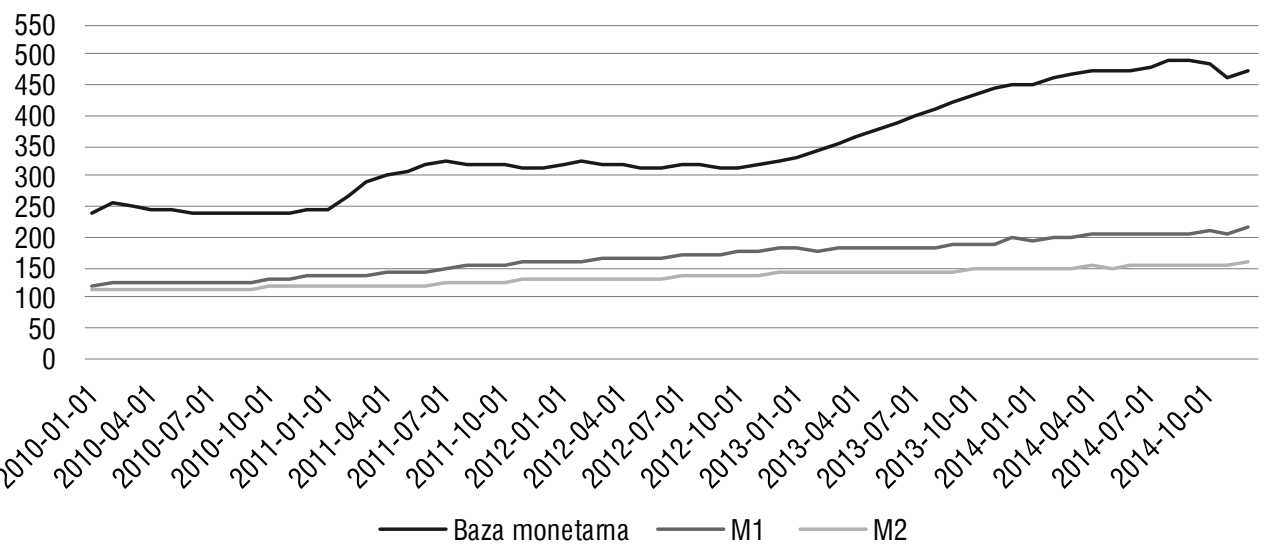

Źródło:https://research.stlouisfed.org/fred2/series/BOGMBASE; https://research.stlouisfed.org/fred2/series/ M1NS https://research.stlouisfed.org/fred2/series/M2NS, dostęp 26.02.2015; EcoWin za prezentacja_Rzonca. pdf Seminarium mBanku - CASE, Skutki niekonwencjonalnej polityki pieniężnej: czego banki centralne nie uwzględniaja w swoich modelach?, Warszawa 17.04.2014. 


\section{Rysunek 4. Baza monetarna i podaż pieniądza w strefie euro (wrzesień $2008=100$ )}

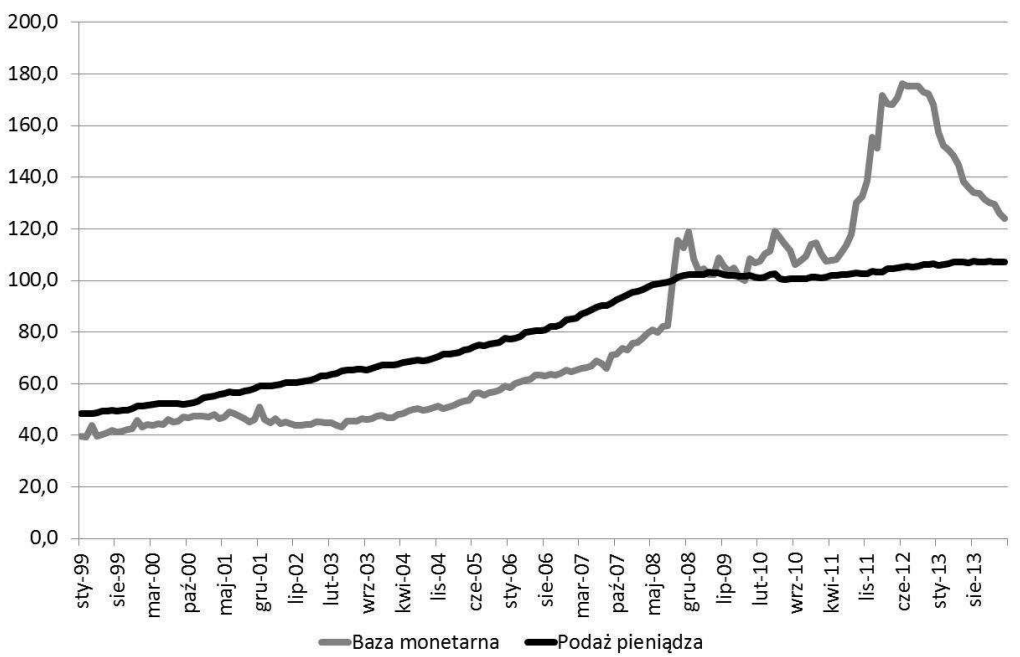

Źródło: EcoWin za prezentacją Rzońca. pdf Seminarium mBanku - CASE, Skutki niekonwencjonalnej polityki pieniężnej: czego banki centralne nie uwzględniaja w swoich modelach?, Warszawa 17.04.2014.

Analizowane dotychczas relacje pokazują, że polityka luzowania ilościowego, chociaż zwiększa bazę monetarną, nie zawsze musi prowadzić do wzrostu podaży pieniądza kredytowego, a programy skupu papierów wartościowych realizowane przez Fed zwiększyły finansowanie podmiotów gospodarczych kredytami w większym stopniu niż programy luzowania ilościowego realizowane w strefie euro.

Warto też podkreślić, że skup aktywów finansowych przez Fed zasilał gospodarkę również z pominięciem sektora bankowego. Programy Fed kierowane były bezpośrednio do podmiotów gospodarczych, w tym także sektora publicznego, zwiększając ilość pieniądza w obiegu gospodarczym (tabela1). Wzrost finansowania pozabankowego sektora gospodarczego w USA sprzyjał procesom ożywienia gospodarczego, stymulując dodatkowo popyt na kredyt bankowy.

Różnice w programach luzowania ilościowego Fed i EBC widoczne są także w dynamice przyrostu ich sumy bilansowej. W EBC był on niższy niż w Fed (rysunek 5).

Jednocześnie, co wydaje się bardzo istotne, wynikający z programów luzowania ilościowego wzrost bazy monetarnej EBC nie zwiększał wyraźnie ilości euro w obiegu. Przyczyniał się natomiast do wzrostu pieniądza rezerwowego (rysunek 6). Polityka luzowania ilościowego prowadzona przez EBC powodowała zatem inne skutki bilansowe niż prowadzona przez Fed. Niski przyrost pieniądza bankowego w strefie euro przy słabej dynamice kredytów w gospodarczych sprzyjał zmianie struktury bilansu EBC, zapewniając sektorowi bankowemu strefy euro wysoką płynność. 
Rysunek 5. Suma bilansowa głównych banków centralnych (wrzesień $2008=100$ )

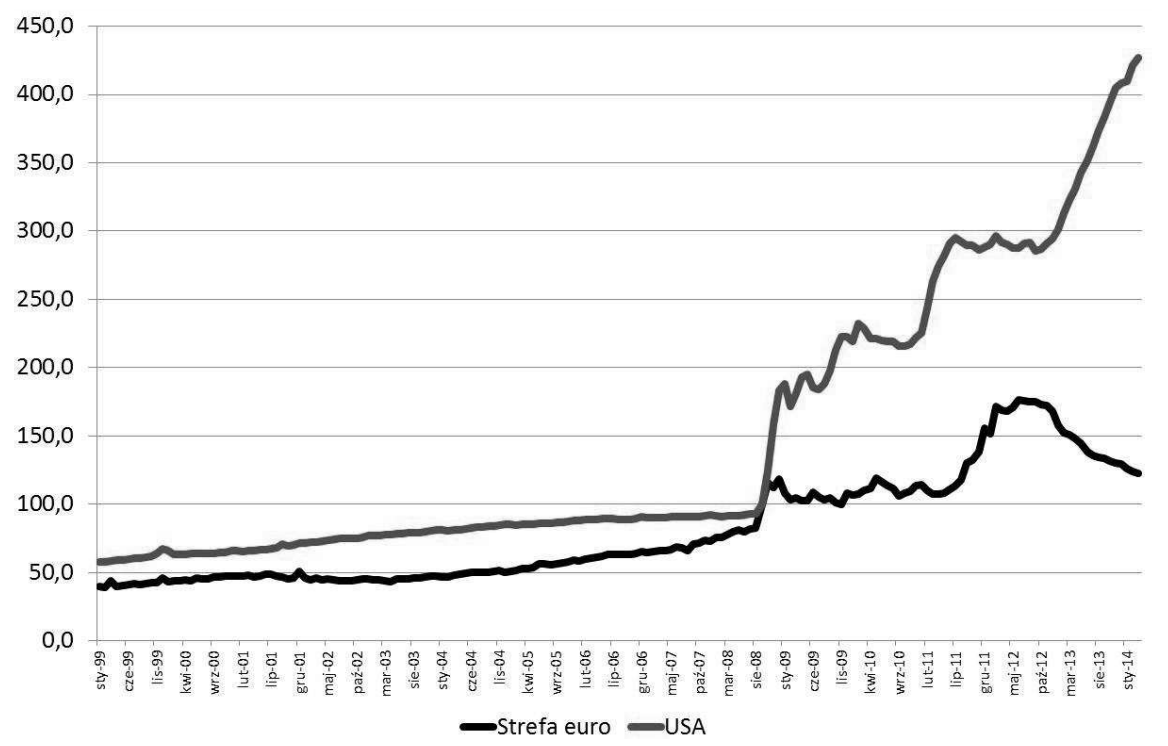

Źródło: EcoWin za prezentacją Rzońca. pdf Seminarium mBanku - CASE, Skutki niekonwencjonalnej polityki pieniężnej: czego banki centralne nie uwzględniaja w swoich modelach?, Warszawa 17.04.2014.

\section{Rysunek 6. Uproszczony bilans Eurosystemu: pasywa}

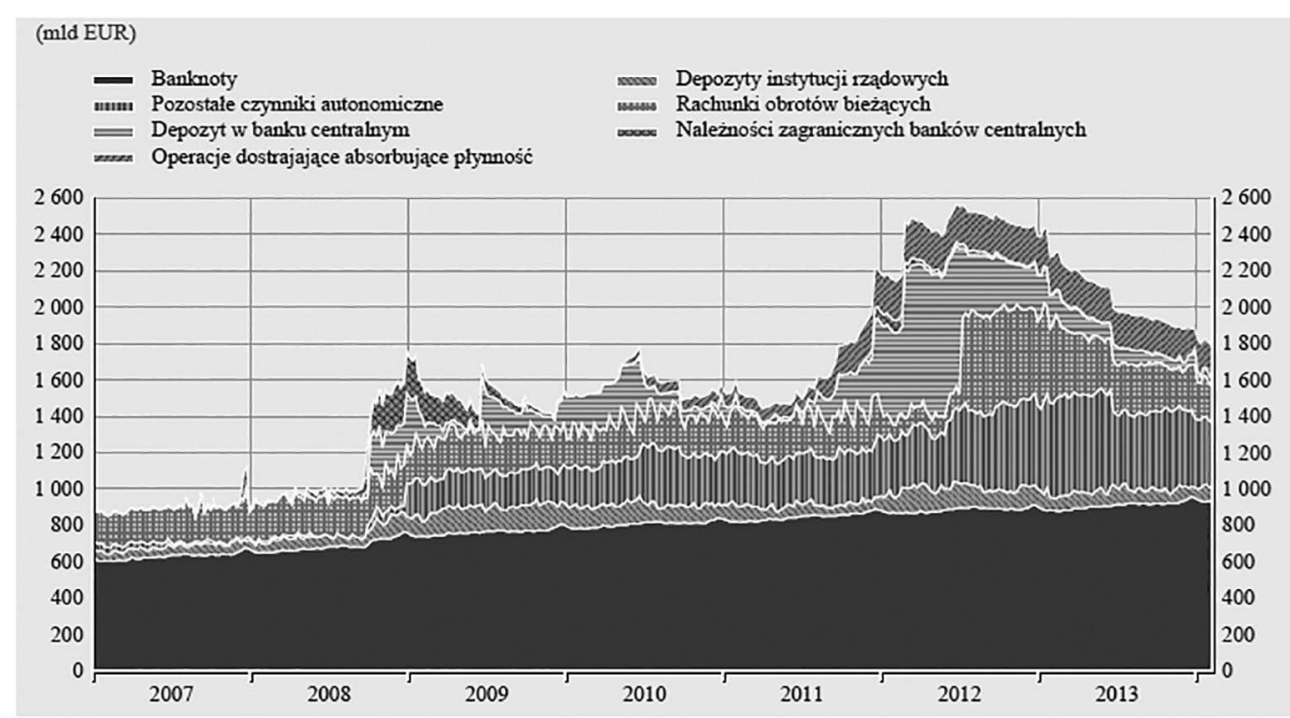

Uwaga: Dane obejmują okres do 14.02.2014.

Źródło: EBC. 
Obserwowana natomiast zmiana struktury podaży pieniądza bankowego w strefie euro (rysunek 7) wskazuje na rosnące ryzyko finansowania banków. Świadczy o tym wzrost tego finansowania krótkoterminowym kapitałem finansowym, przy wyraźnie spadającej dynamice finansowania dłuższymi instrumentami zbywalnymi.

Rysunek 7. Główne składniki M3 w strefie euro (roczne zmiany w \%; skorygowane o efekty sezonowe i kalendarzowe)

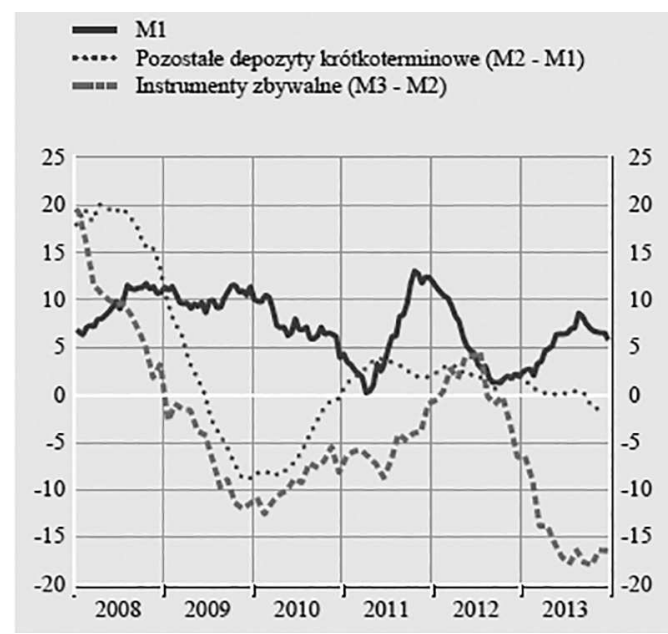

Źródło: EBC.

Podkreślić też należy rosnące w strefie euro zewnętrzne finansowanie pozabankowe podmiotów sektora prywatnego, w szczególności o charakterze rynkowego ich finansowania poprzez emisję obligacji korporacyjnych (rysunek 8).

W strefie euro, opartej na bankowym finansowaniu zewnętrznym, koszt zadłużenia rynkowego w latach 2010-2013 znacznie się obniżył (rysunek 9). W roku 2013 spadł nawet poniżej krótkoterminowego i długoterminowego finansowania bankowego. Nakładający się na to wysoki koszt finansowania emisji akcji - zewnętrznego finansowania własnego - $\mathrm{w}$ warunkach niskich stóp procentowych trend ten wzmacnia. 
Rysunek 8. Finansowanie zewnętrzne przedsiębiorstw strefy euro, według instrumentów (roczne zmiany $\mathrm{w} \%$ )

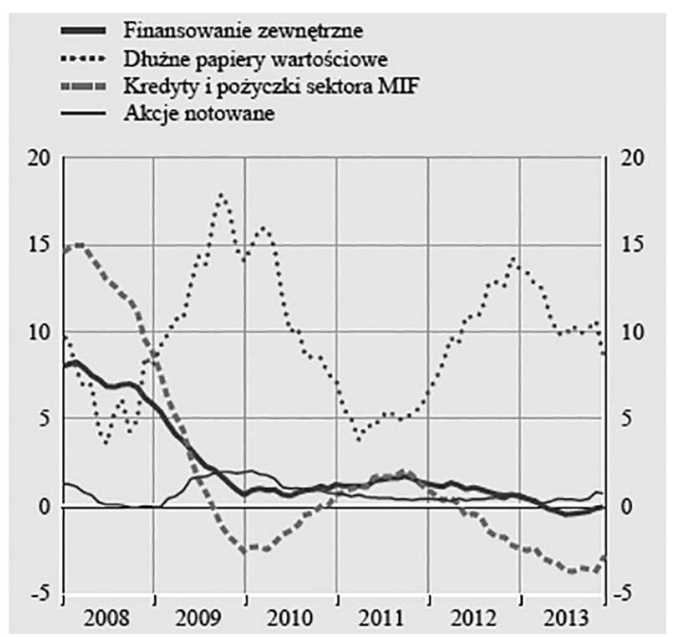

Uwaga: Finansowanie zewnętrzne określane jest jako suma kredytów i pożyczek sektora MIF (niekorygowanych pod względem sprzedaży kredytów ani sekurytyzacji), dłużnych papierów wartościowych, denominowanych w euro notowanych akcji wyemitowanych przez przedsiębiorstwa.

Źródło: EBC.

Rysunek 9. Ogólny koszt finansowania zewnętrznego przedsiębiorstw i jego składniki (oprocentowanie roczne: 3-miesięczne średnie ruchome)

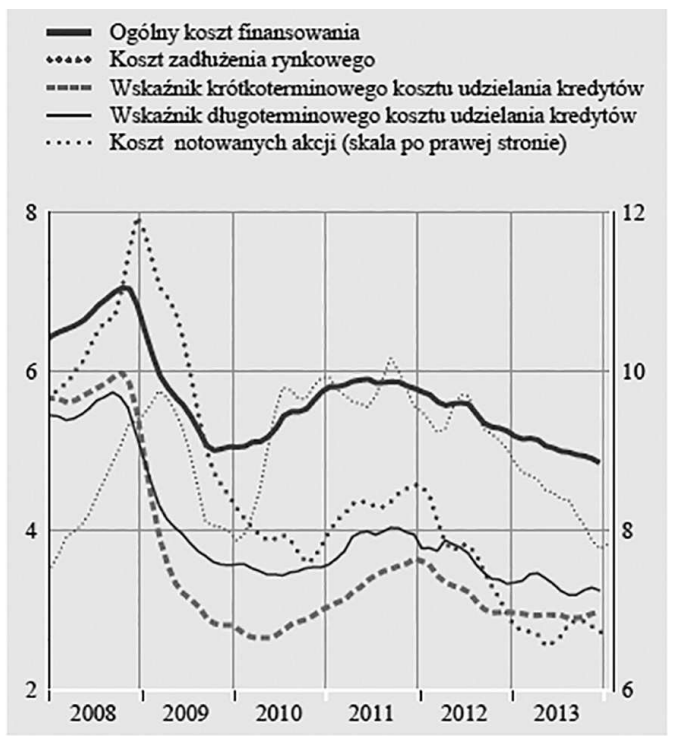

Źródło: EBC; Thomson Reuters; Merrill Lynch. 


\section{Podsumowanie}

Analiza zmian zachodzących w podaży pieniądza w Stanach Zjednoczonych i strefie euro pokazuje, że polityka luzowania ilościowego Fed i EBC z uwagi na swoje właściwości pojawiające się w kolejnych programach luzowania ilościowego nie przyczynia się wprost do kreacji pieniądza kredytowego. Mechanizm polityki luzowania ilościowego okazał się znacznie bardziej skomplikowany niż przypisywane mu cechy. Analizowane zmiany bazy monetarnej, podaży pieniądza, agregatów monetarnych, a także kredytów w USA i strefie euro pokazują, że zachodzące między nimi relacje są uwarunkowane charakterem programu wykupu papierów wartościowych. To programy luzowania ilościowego decydują o zmianie struktury w bilansach banków centralnych, powodując przyrost bazy monetarnej, zmianę proporcji między ilością pieniądza w obiegu a pieniądzem rezerwowym, prowadząc do bardziej lub mniej dynamicznej kreacji pieniądza kredytowego.

\section{Bibliografia}

Banks E., Glanz M., Siegel P., Credit Derivatives: Techniques to Manage Credit Risk of Finance Professionals, McGraw-Hill, London 2006.

Gagon J., Raskin M., Remache J., Sack B., Large-Skale Asset Purchasses by the Federal Reserve: Did the Work?, "Federal Reserve Bank of New York Staff Reports" 2010, No. 441.

https://research.stlouisfed.org/fred2/series/BOGMBASE

https://research.stlouisfed.org/fred2/series/LLBACBQ158SBOG

https://research.stlouisfed.org/fred2/series/M1NS

https://research.stlouisfed.org/fred2/series/M2NS

Raport Roczny, EBC, 2010.

Raport Roczny, EBC, 2013.

Smaghi L.B., Conventional and uncoventional monetary Policy, Keynote lecture at the International Center for Monetary and Banking Studies, Geneva 28 April 2009.

Inman P., What is Operation Twist?, "The Guardian", http://www.theguardian.com/ business/2011/sep/21/operation-twist-federal-resrve-gamble-us-economic-stimulus.

Seminarium mBanku - CASE, Skutki niekonwencjonalnej polityki pieniężnej: czego banki centralne nie uwzględniaja w swoich modelach?, Warszawa 17.04.2014. 


\section{Creation of Credit Money Under Conditions of Central Banks' Quantitative Easing Policy}

The study aims at identification of causes why QE had low impact on the growth of credit money supply in the United States and euro area. The identification of causes is supported by analysis of the asset purchase programs implemented by Fed and ECB. The differences in the policies are considered the main cause of lower growth of lending in the euro area compared to the US.

Keywords: quantitative easing, asset purchase programs, Q1, Q2, Q3, CBPP, SMP, OMT, monetary base, reserve money, credit money, quantity of money in circulation

\section{La création de la monnaie de crédit dans des conditions de la politique d'assouplissement quantitatif des banques centrales}

L'article vise à identifier les causes pour lesquelles l'assouplissement quantitatif avait un faible impact sur la croissance de la masse monétaire de crédit aux ÉtatsUnis et dans la zone euro. L'identification des causes est associée à l'analyse des programmes d'achat d'actifs mis en place par la Fed et la BCE. Les différences dans les politiques sont considérées comme la principale cause de la croissance plus faible des prêts dans la zone euro par rapport aux États-Unis.

Mots-clés: l'assouplissement quantitatif, les programmes d'achat d'actifs, Q1, Q2, Q3, CBPP, SMP, OMT, la base monétaire, la monnaie de réserve, la monnaie de crédit, la quantité de monnaie en circulation

\section{Создание кредитных денег в условиях политики количественного смягчения центральных банков}

Политика количественного смягчения, со времени ее применения крупнейшими центральными банками в качестве инструмента нетрадиционной денежно-кредитной политики, остается постоянным предметом исследований и публикаций. Основная цель исследования состоит в выявлении причин ее слабого воздействия на рост предложения кредитных денег в Соединенных Штатах и еврозоне. Работа проводилась при использовании анализа 
программ покупки активов, реализуемых ФРС и ЕЦБ. Выявленные в ходе исследования различия рассматриваются в качестве основных причин меньшего роста кредитования в еврозоне по сравнению с США.

Ключевые слова: количественное смягчение, программы покупки активов, Q1, Q2, Q3, CBPP, SMP, OMT, денежная база, резервные деньги, кредитные деньги, количество денег в обращении 